\title{
Reform and Exploration of Ability Oriented Application Talents Cultivation in Commodity Trading
}

\author{
Changqiu Wang \\ Ningbo Dahongying University \\ P.R. China, 315175 \\ 370119568@qq.com
}

\begin{abstract}
Application oriented talent training is the key to improve the ability of talents, especially to meet the requirements of the job. The main purpose of this paper is to study how to train the applied talents in the university, such as the specialty of commodity trading. At present, the professional education of commodity trading is still in its infancy. This paper attempts to study the training of professional talents with international vision and trading capacity from the perspective of ability. We must combine the professional education with practice; employ industry experts for teaching, at the same time guide students to carry out practice in enterprises, realizing the combination of knowledge and skills. This paper has certain theoretical innovation and certain innovation significance and application value for the education reform of commodity trading and the practice of new education mode.
\end{abstract}

\section{Keywords-Commodity ; Ability; Applied Talents; Reform}

\section{INTRODUCTION}

Commodity trading specialty is still in the initial stage in China. With the deepening of reform and opening up, China's economy has grown extraordinarily, and commodities plays an increasingly important role, while the demand of commodity industry for talent is also increasing. China's commodity trading professionals are very scarce, which directly affects the development commodity industry. To this end, some domestic universities began to explore the training of professional talents for the industry. Ningbo Dahongying University is one of the earliest universities. Since 2010 , it began to carry out a pilot program of commodity professionals training, establish commodity trading class, trying to train commodity trading talents. Through four years of experiment, the class has made some achievements. In 2014, the school has established an international trade major about the international economy and trade, to train Bulk Stock trading talent, which has been put on the record of Zhejiang Department of Education. In the same year, the total number of enrollment has reached 120 students. At present, its international economics and trade specialty (commodity trading direction) has become the specialty and provincial new specialty of Ningbo Dahongying University, gradually improving its degree of social influence.[1]. While promoting the commodity professional experimental teaching, the university is also actively preparing for the construction of college with commodity business characteristics, so as to realize the synchronous development of personnel training and science research. The construction plan has got the policy and fund support from Ningbo municipal committee and government. Bulk Stock trading specialty mainly trains talents of commodity trading, international trading, consulting services and information processing. At present, the graduates of the specialty has reached 200 students, most of them work in commodity industry, and some have become the manager and supervisor of the industry. This university concentrates on the practice teaching of professional commodity trading, and has invested nearly 20 million Yuan in the construction of four laboratories, including trade, finance, logistics and geographic information. These laboratories provide experiment and practice support for the students and scientific research service for teachers.

\section{The CURRENT Problems OF CHINA'S COMMODITY SPECIALTY}

The current domestic and international commodity professional training is still in infancy, mainly lack of relevant experience and teaching materials, and the theory is insufficient. There are various problems in the teaching process. Taking Ningbo Dahongying University as an example, there are still many needs to be improved in the teaching of commodity trading majors. First of all, we can't get rid of teaching mode influence of traditional applied talents. The traditional teaching method is widely used in universities, which has a great effect on imparting knowledge. However, this pattern undermines creative thinking and the formation of employability. Ningbo Dahongying University has carried out the reform of specialized teaching practice, but this situation still exists, such as how to set and select textbook. Although there are some changes, it does not break through the traditional teaching mode. The designed textbook is still not able to meet the needs of application-oriented talents. Secondly, there is a gap between the setting of the teaching process and the actual situation of employment. The commodity employment requires students not only to have strong professional knowledge, but also to have strong comprehensive quality, even to have practical application ability. Therefore, the innovative talents training should be combined with the school's academic situation and characteristics of application oriented undergraduate colleges and universities. It should focus more 
on the application of innovative talents training. The ability oriented training model has already realized their own advantages and characteristics, but there are still some problems to be solved, such as the difficulties of current semester teaching, training system and application, and the distance of innovative talent training. Finally, it has not fully realized career orientation. The model at present mainly comes from the professional practice system in international trade and practice system, lack of its own characteristics. Although the universities and commodity companies are all exploring cooperative education, and also have established some teaching practice bases, because of various reasons, the current implementation is not in place.

\section{AbILITy ORIENTED COMMOdity TRAding ProfESSIONAL APPLICATION TALENT REFORM IDEAS AND MEASURES.}

First of all, the ability oriented talent training needs to fully consider students' employment requirements. We can establish a training system based on job requirements, and identify the goal of applied talents, and conduct innovative applied talents training through the docking of students and professional post skills[2]. The vigorous development of China's commodity industry presents strong requirement for talents. It needs many professional talents, especially talents of commodities trading, logistics, finance, e-commerce and other severely shorted talents. Now the talents training is still in the pilot phase. Therefore, the development of professional talents training program should fully consider the combination of needs of the commodity industry and social implicated talents, fully study and revise the personnel training program, explore the commodity industry theory, and invite industry experts to participate in the development of talents training program.

Second, carry out the reform of teaching mode. Build the talent training mode combining knowledge, application ability and quality structure, which reflects the concept of applied education[3].Realize the combination of knowledge, ability and post through professional training for commodity exchange, reform traditional teaching concept and design theory, so as to realize all-round and multi-type teaching and complete the ability oriented teaching mode in the practice of teaching. Improve students' ability and fully implement the school's education concept of "student centered" through basic research and practice teaching, so as to deepen the combination of applied talents and theoretical quality, and train the commodity trading capacity.

Third, set up the ability oriented curriculum system. The reform must break the normal procedure and strengthen the curriculum system construction. The original talents curriculum sets curriculum system based on traditional college education talents training program. There are a lot of courses and theoretical courses. After the reform of the curriculum system and the teaching material construction, we will focus on the adaption of the needs of industry development. First, reduce theoretical courses. We will combine the micro economics and macroeconomics and commodity introduction into one course, and combine the international trade theory and policy, international trade, international finance into one courses. Second, improve the practical skills training, establish more courses with independent practice, training students' innovation and practice ability. The courses of commodity trading, real estate integrated logistics simulation, commodity financing can be opened. We will reform the curriculum teaching design and practice system. Current teaching system, due to the restrictions of the curriculum system, can only be implemented in 2 semesters, causing certain limitations. Through the curriculum reform, the practice can be conducted in several semesters to guide students to participate in practice, financial management, futures, securities, trade, the other special skills, improving their comprehensive ability.

Fourth, improve the ability of student's in classroom teaching. In order to improve the ability of students, the classroom teaching is very important. We will try mixed type teaching method, give full play to the initiative of the students in the classroom teaching, so as to improve students' cognition and practice ability through classroom teaching. The practice of flipped classroom has obtained certain practice approval in the university teaching. Flipped classroom reflects the "blended learning" advantage; flip classroom not only can increase the interaction between students and teachers, but also realize students' individualized learning. It is a kind of new hybrid learning, realizing the change from "teacher centered" to "students centered"[4].The classroom practice of commodity trading seizes the new classroom teaching mode, and improve students' ability by flipped classroom. In teaching practice, improve students' learning ability and effect through the curriculum reform, such as the reform of classroom teaching and so on.

Finally, build a new ability oriented practical system .To realize the ability oriented reform, it is necessary to reform existing ability system. According to the requirement of the commodity trading application and compound talents, it has its own practice teaching mode characteristics. We can establish practice teaching system with the effective combination of single experiment, comprehensive experiment, professional experiment, enterprise practice, and expanding ability. Based on the investigation of enterprise needs, construct the ability structure system[5] of commodity talents with the guide of enterprise and the cooperation of colleges and enterprises.[5] The combination of knowledge system and application ability development needs to be realized, which needs to combine the development needs of industry and regional economy to explore the ability system and build students' ability practice structure. New talent cultivation mechanism will boldly innovate commodity talent ability system, and find the training system that is suitable for the ability improvement of China's commodity product industry talents through the joint training of school and enterprise, focusing on cultivation of talents' innovative ability. We can build a knowledge system and industry standards. Through the joint training with enterprise, experience and knowledge will be extended to the entire commodity industries, so as to jointly construct professional standards, and form the commodity industry standards, guiding the development of the industry and eventually realizing the combination of production and research.

\section{GOAL OF REFORM}

To realize the reform, we must set up a certain reform goal. We can set up the goal of reform through the combination of 
specific application to improve the ability of talent. First, we need to build the "people-oriented" concept, and provide highquality applied talents for national marine strategy and commodities industrial development through the construction of talents training system with commodity characteristic and ability orientation. We can also build service platform combining school, enterprise and government. Second, we must reform the way of running school, seize the opportunity of applied undergraduate pilot, innovate education idea, explore the new mode and develop new talents training plan, speeding up the construction of training mechanism of ability oriented applied talents. According to the needs of the commodity industry development, we can construct the commodity application talents training curriculum system to enhance the practice ability. Third, we must establish the research cooperation and mutual win mechanism, through a variety of ways of cooperation between schools and enterprises, to achieve the improvement of school teaching resources and to improve the ability of students employment, even to realize business talent reserves. According to the commodity industry needs, introduce enterprise mentors, improve the ability of teachers and students by participating in the training, and reduce the trial-and-error cost; enterprises find and reserve talents through teaching and practice, realizing the effective combination of the students' knowledge and the actual ability needed by the enterprise. University and enterprise work together to establish win-win practice teaching base, and help students to meet the requirement of work through cooperative training, really achieving the combination of ability and needs. Fourth, we can develop "order training". Currently the enterprise has strong demand which is worth of development and research, so as to help improve it gradually.

\section{THE EFFECTIVENESS AND PrACTICAL EXPERIENCE OF REFOrM}

Ability oriented commodity trading talents training has achieved certain results, and has already gained some experience.

First of all, ability oriented talents training program is designed. On the basis of existing research, Ningbo Dahongying University has combined its design with the needs of commodity trading industry and the development experience of professional personnel training. The program pays more attention to improving the students' ability training objectives, curriculum system, teaching and research institutions, and the requirement to implement applied personnel training. At present, in order to ensure the use requirements of professional knowledge and achieve the independent development of professional practice curriculum, independent practice courses have been set up, such as, commodity trading, commodity logistics, e-commerce. Practice courses account for $33 \%$ of talent training courses, and help students to form abilities of credit, financial management, futures, securities, trading and other special capabilities, improving students' practice ability in many ways.

Second, the blended teaching model in achieved. In order to realize the commodity trading professional ability oriented reform, we must introduce the reform of classroom teaching in the form of pilot. The course of economics theory will pay more attention to the students' exploration of way of thinking in economics and economics practice, uses heuristic teaching and group discussion on the teaching reform of the professional core courses of commodities trade. Many commodity logistics courses are taught in the laboratory environment, Combining the theory and practice of flipped classroom teaching, we have already offered four independent practical courses, and conduct collective teaching. Ask students to experience teaching, simulated operation and professional roles in the laboratory, so as to improve students' positioning of their profession. For example, if the student is willing to work in the commodity product logistics, he/she will choose more logistics practice courses. If the student is willing to work in e-commerce, he/she will choose more e-commerce practice courses. At present, the teaching reform has won the praise of students, and students' ability also has been improved.

Third, the commodity professional students practical training and teaching plan is developed. The complete training and teaching plan is developed to fully take advantage of laboratory and practice or training base. Invite guest professor and commodity industry experts to give lessons, guide students to participate in teaching practice, realizing the expansion and practice teaching of "theory teaching + entrepreneur lectures + industry practice", which ensures quality and enhances students' practice ability. Third, it has formed the commodity trading facing industry and theory and practice teaching covering the commodity supply chain through the development of teaching materials, including the teaching practice implementation of the whole industrial chain of commodities such as agriculture, energy products and metal.

Finally, strengthen the deep combination of industry and research. At present, the school has established cooperation and win-win mechanism with commodity enterprises and industry associations, and also developed relatively stable off-campus teaching practice base. At the same time, it has studied and discussed the cooperation mechanism. Through the investigation of commodity industry, the school has understood the actual need of the commodity industry for talents, and begins to carry out the school-enterprise joint training mechanism of "Going Out" and "Coming In". "Going Out" is to organize the teachers to conduct investigation in enterprises and understand the real needs of the enterprise. It explores the development of talents training program based on industry standard and employment oriented curriculum system. "Coming in" is an introducing mechanism, it introduces senior technical staff in enterprises to school to give lessons for students, improving students' practical ability and eventually achieving the reform goal.

\section{ACKNOWLEDGMENTS}

Funded by: Ningbo Dahongying University teaching reform project "The Key Research and Exploration of the Training Reform of the Ability Oriented Commodity Professional Talents". 


\section{REFERENCES}

[1] Cao Huafang. Research on the development of the international trade applied talents training system based on market demand [D]. Zhejiang University of Technology, 2013

[2] Wu Xujun. The ability to work as a guide to create the application oriented personnel training model [J]. China's higher education, 2014, 05:34-35-45.

[3] Song Kehui, Tian congregations, Peng Qingwen. Applied talents of knowledge, ability and quality structure and cultivation of higher education [J]. China's higher education, 2012,07:94-98.
[4] He Kekang.from essence of "flipped classroom", "flipped classroom" in the future development of our country [J]. education research, 2014,07:5-16.

[5] Wu Zhongjiang, Huang Chengliang. The connotation of applied talents and the cultivation of Applied Undergraduate Talents [J].Research on higher engineering education, 2014,02:66-70.

[6] Wang Rongde. Construction and practice of application oriented talents training system in newly built undergraduate colleges and universities [J]. Research on higher engineering education, 2011,06:102-106. 